\title{
Observations of the Aurora and the Zodiacal Light
}

$\mathrm{I}^{\mathrm{T}}$ $T$ is one of the attractions of astronomy that useful spheres of work are open to all ranges of instrumental equipment from the largest to the smallest, whilst a few phenomena are best observed initially without a telescope at all. In the category of phenomena for naked-eye study are included the aurora and the zodiacal light, though for critical research these also require the camera, photometer and spectroscope. A memoir issued by the British Astronomical Association (32, Part 3) summarizes the work carried out since 1931 by the section under the directorship of Mr. W. B. Housman, dealing with the aurora and zodiacal light.

The observations were made in Great Britain, in which artificially illuminated skies often present serious difficulty in recording these delicate phenomena, and also in Australia, where for several reasons the conditions tend to perfection for the observation of the zodiacal light. The fascination of watching auroral displays is conveyed by the frontispiece, which reproduces a drawing, made by the late Dr. W. J. S. Lockyer from a ship off the coast of
Labrador, of the aurora borealis of August 5, 1932. Owing to their increasing frequency with the rise in solar activity, records of the aurora are of interest to radio research workers and other geophysicists interested in upper air phenomena, as well as to astronomers who look to the sun for clues of their origin.

Observations of the zodiacal light (including the zodiacal band and Gegenschein) are being vigorously pursued in a systematic manner. The reality of both short- and long-period variations in the apparent brightness of the zodiacal band is being investigated by a longitudinal chain of workers from Australia to Japan. The observations made by the Section since 1931 (and especially those made by the Rev. R. B. Bousfield, of Queensland) strongly suggest a general variation with that of the 11-year solar cycle. A chart of the zodiacal band, drawn by Mr. H. Jarvis from Bousfield's observations and his own, and first published in Mon. Not. Roy. Astro. Soc., 1934 , is reproduced in the memoir ; it fills a gap in existing star maps and handbooks.

\section{The Automatic Radio Compass}

$\mathrm{I}^{\mathrm{N}}$ the October number of the quarterly journal entitled Electrical Communication published by the International Standard Electric Corporation, there is a paper by $\mathrm{H}$. Busignies deseribing the automatic radio compass and its applications to aerial navigation.

Ten years ago, attempts were made to develop a compass system, called the 'Hertzian compass', in which the angles indicating the position of a radio transmitter appeared automatically on a graduated scale, similar to the scale of an ordinary magnetic compass. Rough models were made and the essential principles established. Exhaustive trials were made with the collaboration of the French Air Ministry, and commercial production was commenced. It gives an automatic and unbroken visual indication of the direction of a radio station by showing the angle between the direction of this station and the aeroplane's axis. Le Matériel Téléphonique, Paris, constructs a radio compass (R.C. 5 Radio Compass), which indicates the direction of a transmitter on a dial graduated in degrees completely round the circle.

The radio compass may be described as an automatic radio goniometer. It indicates the direction of chosen transmitters which may be situated at any points round the aeroplane. The apparatus is based on the following principle. When a receiving loop aerial turns regularly round a vertical axis, maximum reception occurs every time that the plane of the loop passes in the direction of the transmitter. If the loop turns at a constant speed, a certain number of maxima and minima receptions per second can be observed in a receiver turned on to a transmitter. A rotating speed of five revolutions per second has been chosen as the standard, maxima and minima of receptions taking place at ten per second. The phase of these maxima and minima, that is, the moment at which they occur in connexion with a given origin, depends on the direction of the transmitter in relation to the axis taken as origin. If the location of the transmitter changes in relation to the radio compass, the minima and maxima phases also change, and it is the changing of the phases which is utilized in the apparatus to obtain the automatic indication

A two-phase current generator the phase of which is constant in relation to the revolutions of the rotating loop is placed on its rotating axis. The twophase current creates a rotating field in a magnetic stator which may be compared to the stator of a synchronous motor. This field rotates at a speed double that of the loop. The variable current from the receiver actuates an armature carrying a pointer associated with a dial. In this armature, therefore, an alternating current is produced by the rotation of the receiving loop, and in the stator a fixed phase rotating field by the two-phase machine. Thus the magnetic reactions of one flux on the other give a definite position to the armature, which sets itself perpendicularly to the flux. The radio compass does not itself indicate the 'sense' of direction, but this $180^{\circ}$ ambiguity can be eliminated in several ways. Little if any trouble arises from interference of transmitting stations. The total weight of the apparatus is about $50 \mathrm{lb}$., depending on the size and type of the aeroplane. The guaranteed accuracy of the apparatus is $\pm 2^{\circ}$ for a distance of 300 miles from a 300 -watt transmitter.

Guided by the radio compass, the aeroplane always flies in the direction of the station and, if 
there is no wind, it flies in this direction along a great circle. When there is wind, the pilot determines the drift angle when starting by noticing the course which gives a constant reading of the magnetic compass with a constant indication of the radio compass. Thus, when the correct drift angle has been determined the compass readings can be corrected. In France, both civil and military aviation authorities have submitted the compass to exhaustive trials, and many aeroplanes are already equipped with them.

\section{University Events}

Aberdems.--At the spring graduation held on March 31, the honorary degree of LL.D. was conferred upon the following, among others : Olaf Bloch, head of the Research Department, Ilford Laboratories; Naughton Dunn, surgeon and lecturer in orthopædic surgery in the University of Birmingham ; Prof. A. W. Gibb, emeritus professor of geology in the University; Dr. J. F. Tocher, lecturer in statistics in the University.

CAmbridge.-Dr. F. P. Bowden, fellow of Gonville and Caius College, has been appointed Humphrey Owen Jones lecturer in physical chemistry in succession to Dr. R. G. W. Norrish.

S. D. Elliott has been appointed University demonstrator in the Department of Pathology.

Dr. R. van der R. Woolley has been appointed to the John Couch Adams astronomership and as first assistant observer at the Observatory.

The Amy Mary Preston Read scholarship, value $£ 150$, awarded this year for research in scientific subjects, has been gained by $J$. W. S. Pringle, of King's College, who graduated with a double first in natural sciences in zoology and comparative anatomy in 1934 .

GLAsGow.-Dr. George L. Montgomery has been appointed Gardiner lecturer in the pathology of diseases of infancy and childhood.

Sir William Waters Butler has contributed $£ 100$ towards the cost of erecting the new Chemistry Institute.

At the Commemoration Ceremony on June 16, the honorary degree of LL.D. will be conferred on : Prof. Jan Boeke, professor of histology and embryology in the University of Utrecht; Sir Robert Muir, emeritus professor of pathology in the University of Glasgow ; Prof. Max Planck, emeritus professor of theoretical physics in the University of Berlin; Sir Albert Seward, emeritus professor of botany in the University of Cambridge, recently master of Downing College, Cambridge.

OXFoRD.-Sir William Beveridge, director of the London School of Economics and Political Science since 1919, has accepted the invitation to become master of University College in succession to Dr. A. B. Poynton, and will take office on October 1 (see also p. 619 ).

M. H. Hey, Magdalen College, has been granted the degree of D.Sc. for his work in mineralogy.

The Halley lecture for 1937 will be given on May 28 at 5 p.m. in the University Museum by Dr. B. F. J. Schonland of the University of the Witwatersrand. His subject will be "The lightning Discharge".

\section{Science News a Century Ago}

\section{Brunel on the Thames Tunnel}

At a meeting of the Institution of Civil Engineers on April 11, 1837, Brunel gave an account of the progress being made with the construction of the Thames tunnel, then the greatest work of its kind under construction. The tunnel previously begun by Vazil and Trevithick, he said, had been only about $5 \mathrm{ft}$. high and $3 \mathrm{ft}$. wide, whereas the tunnel now being made was $38 \mathrm{ft}$. wide and $22 \mathrm{ft}$. high, and it was being excavated by the aid of a shield. This shield consisted of twelve parallel frames ranged side by side, each divided into three cells. Each frame was made so that it either derived support from its neighbour or assisted in supporting those adjacent. The advantage of the system which had been adopted of building by rings had been demonstrated by the fact that the brickwork had sustained two eruptions of the river, but had exhibited no sign of rupture. The great inconvenience suffered was through the want of a drain; an attempt to make one had been made, but after getting into a stratum of quicksand $50 \mathrm{ft}$. thick, it had to be abandoned. The land springs were a source of annoyance; many of them were extremely offensive, and produced cutaneous eruptions and were an annoyance to the workmen. The difficulties were great, but they would in time be surmounted.

\section{The University of Cambridge and Gresham College}

IN 1836 William Palmer (1802-58) was appointed professor of law at Gresham College, London. In his inaugural address he dealt in an interesting manner with the history of the foundation of the College. His address occupied two closely printed columns in The Times of April 13, 1837. After referring to the career of Sir Thomas Gresham, Queen Elizabeth's visit to his house in Bishopsgate Street on January 23, 1570, and Gresham's determination to found a college for the several sciences in the City, Palmer quoted from a letter dated March 25, 1575, from the vice-chancellor and senate of the University of Cambridge addressed "To the most accomplished Sir Thomas Gresham, the best maecenas of good learning", urging that the college should be founded at Cambridge and not in London. The letter was in Latin, but the translation ran: "In urging this alone, we would not so strongly or so long contend, unless for the convenient fitness of the place, and for the wholesome state of the air, and usefully for the dignity of the State, and piously for the defence of religion, and fruitfully for the progress of virtue, and happily and fortunately for the advancement of learning and splendidly as well as gloriously for thine own everlasting fame thou mayest erect thy college here rather than in any other place." The college should be at Cambridge or Oxford, but not in London, "to the detriment or almost ruin of either university."

But the compliments of the University could not divert Gresham from his purpose, as seen by his will of July 5, 1575. After his death and that of Lady Gresham, the City and the Mercers Company came into his estates, and the latter applied to Cambridge and Oxford for advice as to the appointments to be made, with the result that of the first seven lecturers three came from Cambridge, three from Oxford and one was appointed on the recommendation of the Queen. 